\title{
The Impact of Speech Training with Symbolic Modelling Technique on Students' Speech Competence
}

\author{
Syafryadin $^{\text {a }}$, Noermanzah ${ }^{\mathrm{b}}$, Wisma Yunita ${ }^{\mathrm{c}}$, Dian Eka Chandra \\ Wardhana $^{d}$, Reni Kusmiartie, a,b,c,dBengkulu University, Bengkulu City, \\ Indonesia, 'Universitas Muhammadiyah Bengkulu, Bengkulu City, Indonesia, \\ Email: $\quad{ }^{a}$ syafryadin@unib.ac.id, $\quad{ }^{b}$ noermanzah@unib.ac.id, \\ cwismayunita@unib.ac.id, d dec.wardhana@unib.ac.id,
}

erenikusmiarti@umb.ac.id

This study was designed to investigate whether Speech Training with Video Modelling Technique is more effective than Speech Training with Systematic Desensitisation and ABC Model Technique, to teach speaking for low and high anxiety students in alleviating students' speaking anxiety and speaking competence hindrances; it was also designed to investigate whether the students having high level anxiety have better speaking competence than the students who have low level anxiety by using Symbolic Modelling Technique, Systematic Desensitisation Technique and ABC Model Technique. This study used Solomon Three-Group design. The population of this study was all fourth semester students in the English Department of Universitas Muhammadiyah Kendari. Three classes were used as the samples of this study. The instruments of this study were speaking or a speech test, an observation checklist, an interview guideline and note taking. The data were analysed quantitatively and qualitatively. The quantitative data were analysed by using analysis of variance (ANOVA), two ways in SPSS 22, while the qualitative data were analysed by using thematic analysis or coding. The findings of this study were that Speech Training with symbolic Modelling Technique (A1) was more effective than Speech Training with Systematic Desensitisation Technique (A2) and ABC Model Technique (A3) in enhancing the students speaking competence. It was proved that A1 (81.22) was higher than the students trained by using A2 (79.08) and A3 (78.15).

Key words: Speech training, symbolic modelling, speech competence, anxiety. 
International Journal of Innovation, Creativity and Change. www.ijicc.net

Volume 13, Issue 6, 2020

\section{Introduction}

Speech or public speaking is an activity which provokes anxiety for foreign and second language education students (Marzec-Stawrarska, 2015; Noermanzah et al., 2019; Mokhlos \& Mukheef, 2020). The students who speak in front of peers and teachers may increase the feeling of nervousness and stress. These feelings may be an obstacle in the development of language proficiency (Peng, 2014 and Piechurska-Kuciel, 2011). According to Nippold, et al. (2005), the students who have weak competence in speaking have big problems in speaking in front of many audiences. It is because the students do not have sufficient vocabulary, mispronunciation of English words, nothing to say, grammatical mistakes, inappropriate intonation, fear and inadequate knowledge and preparation and time allotment. Syafryadin, et al (2019) also said that the problems in speaking can be pronunciation, grammar, vocabulary, or accuracy and fluency. Scott \& Windsor (2000) said that the students, either poor or competent speakers, have anxiety in doing the speech because the students are afraid of forgetting what they have learned. This is supported by James McCroskey's personal report who found that $90 \%$ of the college students experienced moderate to high levels of speech anxiety and the data was gained from several thousand of college students. It is in line with Javid (2014) and Asmari (2015) who conducted the research on measuring the levels of anxiety and the result showed that the students of university suffered medium to high levels of anxiety in public speaking.

Anxiety is one of the factors which influences the students in doing a speech. The largest portion of anxiety in a foreign language classroom belongs to "speaking" FL (Zerey, 2008; Gai and Yang, 2010; Galante, 2012). Woodrow (2006) said that communication with teachers and performing in front of a class are the major contributors to language anxiety in speaking classes. Specifically, giving oral presentations or speech, role-play in front of a class, contribution to formal discussions, answering teacher questions, and informally speaking to teachers were reported as major reasons for learners in class anxiety. Speaking anxiety can be caused by several factors. Those factors are negative evaluation, self-concept, classroom situation, gender, and culture. Several researchers (Gaibani, Ahmed and Elmenfi, fadil, 2014; Nazir, et al. 2014; Mahmoodzadeh, Masoud, 2012; Tseng, 2012; Awan et al, 2010) found that several factors which influenced the speaking anxiety are self-concept, communication apprehension, negative evaluation, gender, lack of confidence, knowledge skills, unpreparedness, worrying about being understood or not, shyness and native speaker effect.

The students' problem is not only speaking anxiety but also speech competence which is apart from speaking competence. Ur (2012:121) stated that students' problems in speaking are inhibition, nothing to say, low participation and mother tongue use. Meanwhile, Notion and Newton (2009:76) emphasise fossilised pronunciation which occurs to the students. According to Jhonson, Jhonson \& Smith (2006), two factors that affect speaking competence are a lack of 
International Journal of Innovation, Creativity and Change. www.ijicc.net Volume 13, Issue 6, 2020

knowledge skills and self-factors. Lack of knowledge skills consists of grammatical ability, vocabulary, pronunciation, and oral practising, while self-factors involve students' condition like guilt, fear, worry, anxiety, and poor ideas. Some previous research found that foreign language anxiety among EFL learners has been singled out as a major factor that impedes the process of language learning and significantly hinders English language proficiency (Liu \& Huang, 2011 and Olivares-Cuhat, 2010). Thus, this speaking anxiety is also related to the students' academic achievement or performance.

Speaking problems explained by the experts similarly happen when the researcher conducted an interview with the lecturers and several students on the students' speaking problems in the English department of Universitas Muhammadiyah Kendari. The researcher found that the students were anxious in speaking or doing a speech in front of the classroom because of a lack of preparation and knowledge skills, or negative evaluation from the teacher or lecturer and the classmates. The students also made mistakes in terms of vocabulary, grammar, pronunciation and mother tongue use. They find it difficult to get a good or appropriate idea of speech. These problems can be solved by giving appropriate techniques or methods. Several studies conducted the research on how to overcome anxiety, but it is only general, such as preparation, discussion, drama, role play and jigsaw (Lin et al, 2014; Gkonou, 2011; Humphrie. 2011). Four techniques or methods which can be applied to overcome speaking competence and speaking anxiety problems are cognitive, behavioural, cognitive-behavioural and skill deficit (Jones and Petruzi, 1995; Kondo and Gifu, 1997; Onwoegbuzie and Dalay, 1996; Sanghvi, 1995; Sud and Prabha, 1996).

Skill-deficit refers to the approach which focuses on how to enhance the students' skill. This intervention can be used to reduce speaking anxiety because anxiety can be overcome by good preparation from the students. Skill-deficit includes skill training and test-taking skill training. This intervention has weaknesses: namely it is focused on the skill which should be mastered by the students, so the students feel burdened. It also causes unnatural body language, still a lack of accuracy and fluency, and behaviour disruptions (Pribyl, Sakamoto, Keaten, 2001). Besides, the training was boring and unattractive (Motevalli, et al. 2013).

Based on cognitive and behavioural approaches' drawbacks, Allen, Hunter and Donohue (as cited in Pribyl, Sakamoto, Keaten, 2001) suggest that the combination skill-deficit or skills training and cognitive or behavioural training is more effective in reducing speaking anxiety than a single technique or method. Furthermore, based on the previous studies, many reseachers conducted the research on investigating the factors of anxiety and overcoming the students' anxiety. However, those strategies are not maximum in alleviating the students' anxiety because those strategies are generally done in a group conversation, difficult to be controlled, boring and unattractive. Syafryadin, et al (2020) conducted the research on conversation analysis which is part of the speaking that made some students anxious in speaking. Most of 
International Journal of Innovation, Creativity and Change. www.ijicc.net

Volume 13, Issue 6, 2020

the previous studies only measure the students' anxiety and not the students' achievement (Asmari (2015), Azizifar, et al (2014), Javid (2014). Liu and Cheng (2014), Tsai (2013), Kim (2007)). After looking at the questionnaire to measure the anxiety, several items are redundant and not clearly sequenced, and divided based on the indicators of measuring anxiety, because Horwitz (1986) and MaCcroskey (2013) were clearly divided about indicators in measuring anxiety, such as communication apprehension, test anxiety, and negative evaluation.

Therefore, the researcher intermingled the speech training with Symbolic Modelling, Systematic Desensitisation and Activating event, Belief and Consequences (ABC) Model technique to alleviate speaking anxiety and speech competence problems. The interventions themselves and the research method are the novelties in this research. Speech training is a training which aimed to improve the students' speech competence and minimise students' speaking anxiety in delivering a speech. By joining this training, the students are expected to cope with the students' speaking competence and anxiety. While, Modelling, Systematic Desensitisation and $\mathrm{ABC}$ Model technique are opted by the researcher because those techniques can be used to alleviate the students' anxiety. Modelling is one of the behaviour techniques and it is related to the teaching and learning process in the classroom. In modelling, the lecturer will use a good speech video which is taken from the internet to be as a model for the students. Modelling is important in teaching and learning because it is derived from observing and imitating the role models and learning behaviours. This technique is useful for alleviating unwanted behaviours, reducing excessive fears or anxiety and facilitating learning of social behaviours and much more (Richards, 2008). However, Systematic Desensitisation and $\mathrm{ABC}$ Model Technique are under behavioural approaches, but those techniques just focus on relaxation exercises and changing a mind-set to deal with the students' speaking anxiety.

\section{Theoretical Framework}

\section{The Nature of Speech Competence}

Speech is one of the speaking activities which uses a clear voice, good expression, stress and intonation, is understandable, uses appropriate pronunciation, grammar, diction, body language, eye contact etc. to convey the meaning to the audience (Martin, (2003), Murcia, (2001), and Valdelber, Sellnow, Valdelber,(2012)). Even, Murcia (2001) stated that speech is one of the speaking activites. Besides, Osborn and Osborn (2014) stated that speech is a public speaking form which aims to deliver ideas well-structured to the audience.

Luoma (2004) stated that speaking is the competence of a human. Competence is the acquisition of knowledge skills and abilities in an appropriate work setting (academic or nonacademic setting). Some scholars define competence as the combination of knowledge, skills and behaviour to enhance the performance. According to the Oxford Advance Dictionary, 
International Journal of Innovation, Creativity and Change. www.ijicc.net

Volume 13, Issue 6, 2020

competence is (of a person) having an ability, power, authority, skill, knowledge, etc., to do what is needed. In short, speech is one of the speaking activities. Speech competence is the ability to convey the idea in a good sequence to many people. It is a part of speaking competence. Speaking competence is delivering ideas of the students to the others to improve their speaking skill. Speaking competence and speech competence are almost the same. It is because speaking competence assesses fluency and accuracy (Ur, 2012), while speech competence does not only assess the fluency and accuracy, but also assesses body langauge, eye contact, how to behave on the stage, how to open, deliver, close the speech, the topic, and other elements in speech (Rooney,2004, and Osborn \& Osborn, 2014). Related to this issue, speaking or speech has become a need for the students to be enhanced and evaluated based on the evaluation system which has been used by the teacher.

\section{Indicators of Speaking Competence and Speech Competence}

Brown (2007) explained the indicators of speaking competence are if the student is able to imitate a word or phrase or possibly a sentence (imitative), and produce short stretches of oral language designed to demonstrate competence in a narrow band of grammatical, phrasal, lexical, or phonological relationship, such as prosodic elements-intonation, stress, rhythm, juncture, intensive ability, response to a very short conversation, standard greetings and small talk, simple requests and comments, and the like (responsive). Take the two forms of either transactional language, which has the purpose of exchanging specific information, or interpersonal exchanges, which have the purpose of maintaining social relationships (interactive, maintain social relationships with the transmission of facts and information (interpersonal), and develop (monolog) oral production including speeches, oral presentations, and story-telling, during which the opportunity for an oral interaction from a listener is either highly limited or ruled out together (extensive).

\section{Speech Training with Video or Symbolic Modelling Technique}

Symbolic modelling involves the students watching behaviour indirectly such as a video. Modelling is recommended to be used in teaching and learning to speak (Spiegler \& Guevremont, 2010:263-266). Video Modelling is one of the behavioural interventions which used a video demonstration as a model to learn. Video modelling can be used to teach all skills in English especially in speaking. Bellini, Akulilan, Hopf (2007) stated that Video Modelling is teaching strategy of technique in which the teacher shows a video of interesting behaviour or interaction of learning to the students either as individual, a small or big group. They also stated that the students can imitate what the teacher shows in the video. Nikopoulos \& Keenan (2007) stated that video modelling is an effective way to teach English either for children with autism or not. It is supported by Charlop-Christy, Le, and Freeman (2003) stated that video modelling can increase the acquisition of the language, is more efficient in terms of time- 
International Journal of Innovation, Creativity and Change. www.ijicc.net

Volume 13, Issue 6, 2020

consuming, assisting the teacher in teaching speaking, and attract students' attention in learning. Besides, Charlop-Christy, Le, and Freeman (2003) also stated that video modelling can be used to reduce the levels of anxiety and distress disorder which happened to the learners. Video Modelling in practice makes teaching and learning easier, fun, is a multi-sensory teaching approach, and the variety of ways it can be used within a teaching setting. Consequently, the lecturers or teachers can use video modelling in teaching speech because by looking at the model, the student can learn how to communicate, and how to do a good oral presentation or speech.Video modelling is one of the visual illustrations that can be useful to help the speaker to deliver the meaning.

\section{Speech Training with Systematic Desensitisation Technique}

Systematic Desensitisation was developed by Joseph Wolfe and was designed for clients with phobias and speaking anxiety is one of the phobias. Systematic Desensitisation is one of the methods which can be used to reduce speaking anxiety by using several steps in relaxation. This treatment follows a process of "counter-conditioning" meaning the association between the stimulus and the anxiety is weakened through the use of relaxation techniques, anxiety hierarchies and desensitisation (Weiten, 2007). The simple procedures of Systematic Desensitisation are (1) individuals first learn procedures for relaxation, (2) learn how to apply these to each of the anxiety-producing events that they visualise, (3) they learn to remain relaxed when they encounter these anxiety-producing situations in real life (Varderber, Sellnow, and Varderber, 2012).

\section{Speech Training with ABC Model Technique}

The ABC model was proposed by Albert Ellis (cited in Rector, 2010) which has been used until now. This model proposes three steps in alleviating the anxiety for people or learners.

A stands for Activating Event or objective situation. The first column records the objective situation, that is, an event that ultimately leads to some type of high emotional response or negative dysfunctional thinking. In other words, it refers to the objective description of what occurred in the situation in which the person became disturbed.

B stands for Beliefs. In the second column, the student writes down the negative thoughts that occurred to them and explained why the situation happened to them.

C stands for Consequence. The third column is for the negative feelings and dysfunctional behaviours that ensued. The negative thoughts of the second column are seen as a connecting bridge between the situation and the distressing feelings. In this part, the consequence is also 
International Journal of Innovation, Creativity and Change. www.ijicc.net

Volume 13, Issue 6, 2020

related to feelings and behaviours about the belief causes. The third column $\mathrm{C}$ is next explained by describing emotions or negative thoughts that the student thinks are caused by A. This could be anger, sorrow, and anxiety (Dryden and Neenan 2004:16-17 and Beck, 2011:31).

\section{Nature of Anxiety}

Many researchers have defined anxiety or foreign language anxiety which is faced by people or the students. Horwitz, et al (1986) says, "Anxiety is the subjective feeling of tension, apprehension, nervousness, and worry associated with the arousal of the autonomic nervous system". Besides, Young (1992) stated that anxiety also is a complicated psychological phenomenon which can be connected to language learning. More specifically, MacIntyre and Gardner (1989) said that foreign language anxiety is apprehension which happened in foreign or second language contexts, such as speaking, listening, and learning. In other words, it refers to the worry and negative emotional reaction arousal when learning or using a second or foreign language. Mayer (2008:27) defined anxiety as a state of intense agitation, foreboding, tension, and dread, occurring from a real or perceived threat of impending danger. Besides, Mayer (2008) also stated that anxiety is a mind-body reaction that occurs instantaneously and its effects are felt psychologically and behaviourally at the same time. In defining anxiety, Mayer (2008) also defined school anxiety as anxiety which happens in the school by the students during the teaching and learning process. However, Cassady (2010) introduced the term academic anxiety as "a unifying formulation for the collection of anxieties learners experience while in schools" (p. 1).

\section{Methods}

The experimental design of this study was Modified Solomon Three-Group Design. The Solomon Three-Group Design is an experimental research which aims to compare three groups which use experimental and control groups; both the main effects of testing and interaction of testing are determinable (Ary et al, 2010:309). This study compared three groups which consisted of one experimental class and two control classes. Ary et al (2010:302) stated that experimental group is the group that is given the independent variable treatment, the control group is the group which that does not receive the experimental treatment. It receives a different treatment or no treatment at all. Therefore, it is intended to investigate the result of pre-test and post-test of three classes as one way to investigate the effect of using Speech Training with Video Modelling Technique in experimental class on alleviating students' speaking anxiety and speech competence constraints. In the control class, the students were given speech training with Systematic Desensitisation and ABC Model Technique.The detail design was described in Table 1. 
International Journal of Innovation, Creativity and Change. www.ijicc.net

Volume 13, Issue 6, 2020

Table 1: Schema of Solomon Three Group Design with Three Treatments (3x2)

\begin{tabular}{|l|l|l|l|l|l|l|}
\hline \multirow{2}{*}{$\begin{array}{l}\text { Levels } \\
\text { of Anxiety }\end{array}$} & \multicolumn{2}{|l|}{$\begin{array}{l}\text { Speech Training with } \\
\text { Speech Training } \\
\text { with Modelling } \\
\text { Technique (A1) }\end{array}$} & $\begin{array}{l}\text { Technsitization } \\
\text { (A2) }\end{array}$ & $\begin{array}{l}\text { Speech Training with } \\
\text { ABC Model Technique } \\
\text { (A3) }\end{array}$ \\
\cline { 2 - 7 } & Pre-test & Post-test & Pre-test & Post-test & Pre-test & Post-test \\
\hline Low (B1) & A1-B1 & A1-B1 & A2-B1 & A2-B1 & A3-B1 & A3-B1 \\
\hline \multirow{2}{*}{ High (B2) } & A1-B2 & A1-B2 & A2-B2 & A2-B2 & A3-B2 & A3-B2 \\
\cline { 2 - 7 } & A1-B1-B2 & A2-B1-B2 & A3-B1-B2 \\
\hline
\end{tabular}

The sample of this study was all of the students in English Department of Universitas Muhammadiyah Kendari who were registered in the fourth-semester in the academic year of 2015/2016. The total population was 116 students which consisted of three classes. This study used anxiety test, speech test, observation checklist and note taking as instruments. The data were analysed by using the SPSS Program.

\section{Results and Discussion}

\section{Results}

Table 2: Summary of Data Analysis (Schema of Solomon Three Group Design with Three Treatments $(3 \times 2))$

\begin{tabular}{|c|c|c|c|c|c|c|}
\hline & \multicolumn{6}{|c|}{ Speaking Competence } \\
\hline \multirow{2}{*}{$\begin{array}{l}\text { Intervention } \\
\text { Levels } \\
\text { of Anxiety }\end{array}$} & \multicolumn{2}{|c|}{$\begin{array}{l}\text { Speech Training } \\
\text { with Video } \\
\text { Modelling } \\
\text { Technique (A1) }\end{array}$} & \multicolumn{2}{|c|}{$\begin{array}{l}\text { Speech Training with } \\
\text { Desensitization } \\
\text { Technique } \\
\text { (A2) }\end{array}$} & \multicolumn{2}{|c|}{$\begin{array}{l}\text { Speech Training with } \\
\text { ABC Model Technique } \\
\text { (A3) }\end{array}$} \\
\hline & Pre-test & Post-test & Pre-test & Post-test & Pre-test & Post-test \\
\hline Low (B1) & 72.8750 & 86.6250 & 71.4444 & 83.7778 & 68.5000 & 78.0000 \\
\hline \multirow{2}{*}{ High (B2) } & 65.6000 & 78.3333 & 65.0625 & 76.4375 & 65.3750 & 78.1875 \\
\hline & 68.1304 & 81.2174 & 67.3600 & 79.0800 & 66.2273 & 78.1364 \\
\hline
\end{tabular}

Based on data in table 2, firstly, the speech mean score of low anxiety students who trained by Video Modelling Technique (A1) inclines from the pre-test to post-test or from 72.87 becomes 86.62. It is same as the speech mean score of high anxiety students who got improvement from pre-test to post-test namely 65.60 to 78.33 . Secondly, the speech mean score of low anxiety students who trained by the Desensitisation Technique (A2) inclines from the pre-test to posttest or from 71.844 to 83.77 . It is same as the speech mean score of high anxiety students who got improvement from pre-test to post-test namely 65.06 to 76.43. Thirdly, the speech mean score of low anxiety students who trained ABC Model Technique (A3) increases from the 
International Journal of Innovation, Creativity and Change. www.ijicc.net

Volume 13, Issue 6, 2020

pre-test to post-test or from 68.50 becomes 78.00 and the speech mean score of high anxiety students also got improvement from pre-test to post-test namely 65.37 to 78.175 .

Moreover, the data showed that Speech Training with Video Modelling Technique was better than the Systematic Desensitisation and ABC Model Technique because the mean score of post-test from the students who were trained by Video Modelling Technique was higher than Systematic Desensitisation and ABC Model Technique, namely 81.2174 was higher than 79.0800 and 78.1364. Furthermore, the data show that low anxiety students had a better speech competence than high anxiety students. It was proved by the mean score of the low anxiety students namely 86.6250 and 83.7778 . However, the speech mean score of low anxiety students who trained by $\mathrm{ABC}$ Model Technique is lower than high anxiety students, although the range was not quite as big namely 0.1875 . Furthermore, the data showed that the interaction between anxiety levels and speech training in terms of speech competence, because anxiety influenced the competence of the students after getting Speech Training with Video Modelling, Systematic Desensitisation, and the ABC Model Technique. It was proved by the improvement of the speech scores from pre-test until post-test.

Figure 1. Interaction between Anxiety and Speech Training in terms of Speech Competence

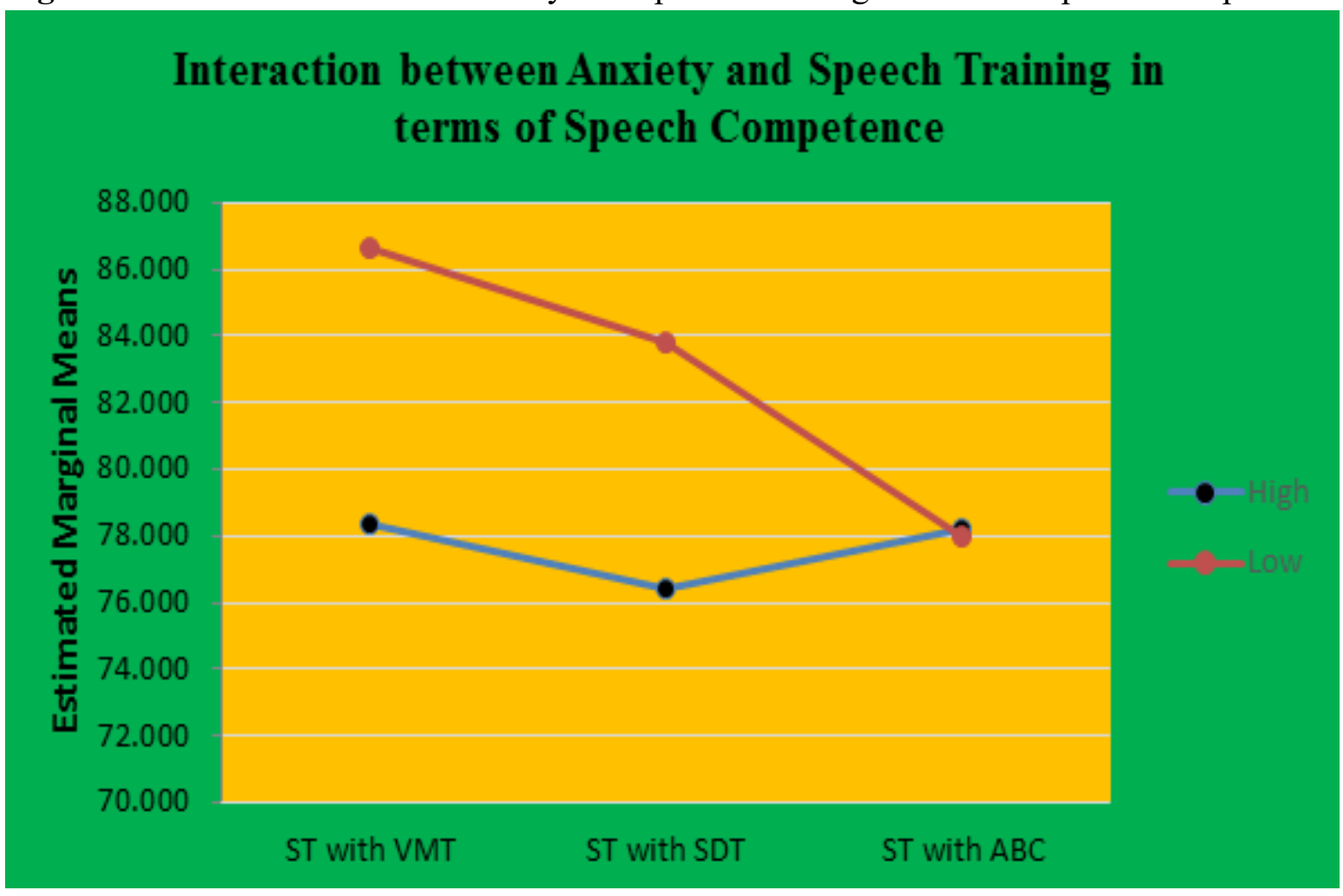

Based on the figure 1, it shows that there is a difference among three interventions in terms of speech score for low and high anxiety students. For low anxiety students, the speech score of 
International Journal of Innovation, Creativity and Change. www.ijicc.net

Volume 13, Issue 6, 2020

the students trained by using ST with VMT, SDT and ABC Model Technique are 86.625, 83.77, 78.00, while for high anxiety students they were 78.33, 76.43, and 78.187. Besides, the curve indicates that those interventions are effective in minimising students' speech anxiety and increase the students speech competence. However, ST with VMT is more effective than the others. Furthermore, the ST with VMT and SDT are more effective for the low anxiety students, but ST with ABCMT is effective for high anxiety students. Consequently, the curve shows the interaction between anxiety and speech training in terms of speech competence because of those reasons, and mean scores of high anxiety and low anxiety students meet in one point in the curve after all interventions were calculated together.

\section{Hypothesis Verification}

Hypothesis verification is used to verify the hypothesis of this study whether null hypothesis (Ho) is rejected or accepted. The calculation of normality, homogeneity and other calculations can be seen in appendix 6 . Based on the result of calculation, it can be concluded as follows:

1. Because based on the analysis of variance calculation among Speech Training with Video Modelling Technique (A1), Systematic Desensitisation (A2) and ABC Model (A3) to teach speaking (speech) at the English Department of Universitas Muhamadiyah (see appendix 6 ), the significance is higher than 0.005 . It means that null hypothesis is accepted because there is no difference speech score of the students trained by using A1, A2, A3. However, after looking at the mean score of the students' speech (see appendix 6), the mean score of the students' speech trained by A1 (81.22) is higher than the students trained by using A2 (79.08) and A3 (78.15). Based on the calculation by using SPSS, those speech training with three different techniques are effective to teach speech, but Speech Training with VMT is more effective than SDT and ABC Model Technique.

2. Because based on an analysis of variance calculation, Sig. (obtained) 0.000 is higher than 0.05. This means that the null hypothesis is rejected and there is the different speech score for the students who have low and high anxiety. Then, after looking at the descriptive statistic table (see appendix 6), the mean score of the students' speech having low anxiety (77.65) is higher than those who have high anxiety (83.00). It indicates that the students who have low anxiety have better speech competence.

3. Because based on tests of between subject-effect (see appendix 6) shows that sig. $(0.047$ (obtained) $)$ is lower than 0.05 , it indicates that null hypothesis is rejected. It means that there is an interaction between Speech Training (with Video Modelling Technique, Systematic Desensitisation and ABC Model Technique) and students' anxiety levels in terms of speech competence. 


\section{Discussion}

This part comprises three items which discuss the findings of this study. Those items are: The effectiveness of Speech Training with Symbolic or Video Modelling Technique (STVMT) compared to Speech Training with Systematic Desensitisation Technique (STSD) and ABC Model Technique, the students with low anxiety have better speech competence than those with high anxiety; there is an interaction between speech training (Speech Training with Video Modelling Technique, Systematic Desensitisation Technique, and ABC Model Technique) and anxiety levels in terms of speech competence. The Effectiveness of Speech Training with Video Modelling Technique (STVMT) is compared to Speech Training with Systematic Desensitisation Technique (STSD) and ABC Model Technique.

Speech Training with Symbolic or Video Modelling Technique is more effective than Speech Training with Systematic Desensitisation Technique and ABC Model Technique for several reasons.

Firstly, Speech Training with Video Modelling Technique offered a model for the students onhow to open, deliver and close the speech in front of many people. Consequently, the students imitate what the video shows such as, body language, eye contact, pronunciation, intonation, stress, stage act, and media use in delivering a speech. Thus, the students can increase their speech competence because the students were active in speaking or giving a speech. As Ur (2012) said that the characteristics of successful speaking activities are talking a lot, participating in the classroom, having high motivation and using acceptable language well. Besides, Brown (2007) mentioned that the indicators where the students have good speaking competence or are developing an oral presentation, maintaining the interaction with the others in small talk, speaking fluently and acccurately. Related to STVMT, CharlopChristy, Le, and Freeman (2003) stated that video modelling can enhance the acquisition of the language because the students acquire the language by looking at a video and implementing it in their speech. Directly, the students will get exposure to accuracy, fluency, and all the parts of the speech from the beginning until the end. Varderber, Sellnow, and Varderber (2012) and Spielger and Guevremont (2010) stated that STVMT can help the students in inclining their ability in speaking because after looking at the video, the students will absorb the knowledge from the speaker in the video and practise their speech either individually or in a group.

Secondly, STVMT alleviated the students' anxiety in giving a speech because the students were asked for looking, listening, analysing and practising what the students have seen. Besides, the students feel better in terms of anxiety because the students have seen a good example of a speech video, so they know what to do and what not to do in giving a speech. In this training, the students were very enthusiastic because they like to watch the interesting video which was showed by the lecturer and they were active to speak in the classroom. This is supported by 
International Journal of Innovation, Creativity and Change. www.ijicc.net Volume 13, Issue 6, 2020

Charlop-Christy, Le, and Freeman (2003) who said that STVMT provides the students with all the steps in delivering a speech from initiating until an ultimate point. As a result, the students were ready to give a speech with good preparation and not anxious to convey the speech in front of many people. Varderber, Sellnow, and Varderber (2012) also pointed out that STVMT decreases the students' anxiety because the students are trained and prepared to be better speakers.

Thirdly, the students were not bored in speaking in class because the students saw the attractive speech video modelling. As Charlop-Christy, Le, and Freeman (2003) said that STVMT provides the visual presentation for the students, so the students will find it enjoyable and fun speaking class.

Fourthly, STVMT is helpful for the lecturer because he/she can use the video as a media for teaching speech. As result, the lecturer can maximise the facility to assist the students in improving their speaking competence. Akulilan and Hopf (2007) explained that Video Modelling technique can support the lecturer in teaching and learning. It means that VMT can be used by the lecturer to teach speech in the classroom.

After knowing the reasons why STVMT is more effective than other speech training with different techniques, it does not mean that Speech Training with Systematic Desensitisation Technique and $\mathrm{ABC}$ Model Technique are not effective for the students. They are also effective, but after looking at the mean score of students' speech, STVMT is higher than the STSD and the STABC Model Technique.

First, the STSD is effective for improving students' speaking competence because the students are trained manually without using Video Modelling. The students practised their speech in front of many people. The students were asked to do relaxation to refresh their mind before or after implementing the speech training. According to Weiten (2007), Systematic Desensitisation is useful for analysing the students' problems, either anxiety or speaking problems from the highest priority to the least one. After knowing the students' problems, the lecturer or trainer can solve the problems by giving relaxation movements and speech training to improve the students speaking competence and decrease the students' speech anxiety. Second, the STABC is also effective for improving students' speaking competence because in the $\mathrm{ABC}$ Model Technique, the students are asked to activate the event, belief and consequence from the problems and after that, the students were asked to find the solution by themselves and there would be assistance from the lecturer. Dryden and Neenan (2004) and Beck (2011) stated that the ABC model technique is useful to reduce the students' speech anxiety. Varderber, Sellnow, and Varderber (2012) explained that Speech Training with ABC Model Technique can improve the students' speaking competence and reduce the students' speech anxiety. 
International Journal of Innovation, Creativity and Change. www.ijicc.net

Volume 13, Issue 6, 2020

Based on the implementation of Speech Training with Video Modelling Technique, Systematic Desensitisation Technique and ABC Model Technique, the students improved in terms of speaking competence. However, the students had problems in terms of grammar, pronunciation, repetition, body language, mother tongue, eye contact, intonation, diction and topic of the speech. Ur (2012) stated that the students' problems in speaking are inhibition, fluency, accuracy, and low participation. Besides, Ur (2012) also stated that the students are a success in speaking if the students have high participation, high motivation and speak a lot. For three classes, most of the students got those problems before treatment and after treatment. However, the mistakes were fewer after the students got treatment.

\section{The Students with Low Anxiety Have Better Speech Competence than Those with High Anxiety}

Anxiety is one of the students' problems in speaking. Speech Anxiety is apprehension that students face when the students give a speech in front of many people. According to Mayer (2008:27), anxiety is a state of intense agitation, foreboding, tension, and dread, occurring from a real or perceived threat impending danger. Anxiety can occur in an academic setting or nonacademic setting. Cassady (2010) introduced the term academic anxiety as "a unifying formulation for the collection of anxieties learners experience while learning in schools, for example, learning speaking". Anxiety has three types: One of them is situation-specific anxiety. Ellis (1994) stated that situation specific anxiety is anxiety which happened in particular situation, context and phenomenon. Related to this, the students at school experienced situation-specific anxiety because they would give a speech in certain situations either in the classroom or outside the classroom. The anxiety of the students can be low and high. Anxiety can be caused by several factors, such as negative evaluation from friends and teachers or lecturers, gender-based, self-perception, afraid of making mistakes, cultural differences and lack of knowledge skill (Tseng, 2012, p. 78-91). Hence, students' speech anxiety becomes obstacles in learning to speak.

Based on the finding of this study, the students with low anxiety had better speech competence than the students with high anxiety. The students with low anxiety had good self-confidence to speak in individual or a group and thought that they had sufficient knowledge about the speech itself. Besides, the students with low anxiety were motivated in learning speaking. They were interested in joining every step in speech training because speech training will be fruitful for their speech competence. Furthermore, they were dominantly speaking in the classroom because they were willing to express and explore their ideas.

Corel (2007) stated that the low anxiety student is the student who hasthe courage to do an oral presentation or oral speech in public. They voluntarily gave a speech without being pointed to 
International Journal of Innovation, Creativity and Change. www.ijicc.net Volume 13, Issue 6, 2020

by the lecturer. According to Nevid, Rathus and Green (2003), students with low anxiety have several characteristics in terms of physiology, cognitive, behavioural and emotional attributes.

Firstly, in terms of physiology, the students with low anxiety will not tremble and respire during giving a speech. Besides, the students can arrange their breath and movement. The students can also control their speaking and respond to the questions well. Secondly, in terms of the cognitive, the students with low anxiety can find out a good idea, answer the questions, think critically, absorb the knowledge, focus on the speech and have the ability to deal with the problems. Thirdly, in terms of behavioural and emotional aspects, the students with low anxiety can arrange their position in giving speech based on the needs. Then, the students can arrange their emotions during speech as the intonation during a speech can sometimes be high and low.

Sumadinata (2004) added the characteristic of the students with low anxiety in terms of the motorist. Actually, it is related to the movement and eye contact of the students during the speech. The students can maximise their body language and eye contact in giving a speech. In this point, the students will use appropriate eye contact and body language accordance with the speech itself. Davison, Neale and Kring (2006) mentioned that the students with low anxiety are not afraid of getting a negative comment, feedback or evaluation from the lecturer and mates. The comment or feedback is not a big deal for the students with low anxiety because they think that the feedback or evaluation or comment can be as input for them to be better in terms of speaking competence. They will be pleased to listen to the feedback and correct their mistakes. Besides, the students with low anxiety will not be afraid of making mistakes in giving a speech because they think that as students, they are in process of learning. Thus, making mistake is usual for them, but after getting the correction, they will repair it.

In contrast, the students with high anxiety improved in terms of the speaking competence but it was not as high as the students with low anxiety for two classes, but one class had the result that the speech mean score of the students with high anxiety was higher than those have low anxiety. The students with high anxiety felt afraid of speaking in the classroom because they were afraid of getting a negative comment and laughed by their mates. Besides, the students with high anxiety tended to be shy in speaking and were silent, but after getting speech training, the students were braver than before even though their improvement was not as high as the students with low anxiety.

According to Nevid, Rathus and Green (2003), the students with high anxiety have characteristics in terms of physiology, cognitive, behavioural and emotional. The first, in terms of physiology, the students will be tense, tremble, perspire, and awkward in giving a speech. Consequently, their performance in speaking may not be better. The second, in terms of cognitive, the students with high anxiety will find difficulty in overcoming the problems related to the speech and late to respond the questions. The third, in terms of behavioural and 
International Journal of Innovation, Creativity and Change. www.ijicc.net

Volume 13, Issue 6, 2020

emotional, the students with high anxiety will find difficult to control their emotions, breath, movement during oral presentation or speech.

In brief, based on the finding of this research, it can be concluded that the students with low anxiety have a better speaking competence than those have high anxiety. However, both the students with low and high anxiety improved in terms of speaking competence, although the students with high anxiety have the mean score of speech lower than the students who have low anxiety.

There is an Interaction between Speech Training (Speech Training with Video Modelling Technique, Systematic Desensitisation Technique and ABC Model Technique) and Anxiety Levels in terms of Speaking Competence

Based on the findings of this research, anxiety is one of the factors which influences the students' speaking competence because anxiety can be obstacles for the students to speak in public. Speech training is one of the ways which used to improve the students' speech competence and reduce the students' speech anxiety (Varderber, Sellnow, and Varderber, 2012).

In speech training, the students were trained to be good speakers. The trainer provided materials, such as anxiety types, speech itself, speech opening, speech delivery, speech closing, intonation, stress, grammar, pronunciation, eye contact, body language and media. First, the lecturer explained about the anxiety problems. Second, the lecturer elaborated how to write the speech, open the speech and close the speech. Third, the lecturer asked them to practise in a group. In a group, the students could share their ideas with other friends and discuss together. Then, they did not only practise their speech, but also practised their critical thinking. Fourth, the lecturer trained them about grammar which was related to the speech. Fifth, the lecturer trained them about the appropriate intonation, stress and pronunciation. In pronunciation, the lecturer asked them to search on the Longman dictionary or Oxford dictionary.

Sixth, the lecturer also trained them about good eye contact and gesture in giving a speech. Seventh, the lecturer asked them to provide media and they practised their speech by using their media. In speech training, the students were also taught how to behave on the stage during a speech. The students who had low and high anxiety were suitable to join this speech training because those students were able to overcome their speech anxiety and enhance their speaking competence. The students with low anxiety had high motivation and high participation in speaking because they were not anxious to speak in front of their friends. The students with high anxiety were still shy to speak, but after getting the speech training, the students were active in the classroom, even though the students made mistakes - either grammar, pronunciation, eye contact, gestures, intonation and other errors. 
Based on the calculation result, it indicates that the students who have low anxiety and high anxiety got improvement in terms of speech competence after joining speech training. Although, the mean of speech score of the students with low anxiety was higher than the students with high anxiety after getting speech training with the Video Modelling Technique and Systematic Desensitisation Technique. However, the students who trained by using the ABC Model Technique was different from other classes because the mean score of the students' speech which had high anxiety is higher than those who had low anxiety. Therefore, it can be said that the speech training with the Video Modelling Technique and the Systematic Desensitisation Technique had a significant effect on the students with low anxiety in terms of speech competence, while ABC Model Technique gave significant effect on the students with high anxiety.

\section{Conclusion}

Based on the data description and data analysis, the findings of this research can be drawn as follows.

1. Speech Training with Video Modelling Technique (STVMT) is more effective than Speech Training with Systematic Desensitisation Technique (STSD) and ABC Model Technique in enhancing the students' speech competence and decreasing the students' speech anxiety at the fourth-semester students of Universitas Muhammadiyah Kendari in the academic year of 2016 .

2. The students who have low anxiety have better speech competence than the students who have high anxiety at the fourth-semester students of Universitas Muhammadiyah Kendari in the academic year of 2016 .

3. There is an interaction between speech training (Speech Training with Video Modelling Technique, Systematic Desensitisation Technique and ABC Model Technique) and anxiety levels in terms of speech competence at the fourth semester students of Universitas Muhammadiyah Kendari in the academic year of 2016. Thus, ST with VMT and SDT are effective for low anxiety students, while ST with ABCMT is effective for high anxiety students. 
International Journal of Innovation, Creativity and Change. www.ijicc.net

Volume 13, Issue 6, 2020

\section{REFERENCES}

Ary, D. et al. (2010). Introduction to Research in Education. Eight Edition. USA: Wadsworth, Cengage Learning.

Asmari, A. R. A. (2015). "A Comparative Analysis of Preparatory Year Students' FL Anxiety”.International Journal of English Linguistics; 5(4):50-63. Retrieved from www.ccsenet.org/ijel/

Awan, R. et al.2010. An investigation of foreign language classroom anxiety and its relationship with students' achievement.Journal of College Teaching \& Learning, $7(11): 33-40$.

Azizifar, A. et al. (2014) “The Effect of anxiety on Iranian EFLlearners speakingskill”.,International Research Journal of Applied and BasicSciences. 8 (10):1747-1754

Bailey, K. (2008). "Issues in teaching speaking skill to adult ESOL learners". In J. Coming, B. Garner, \& C. Smith (Eds.), Review of adult learning and literacy: Volume connecting research, policy, and practice (pp. 113-164). New York: Taylor \& Francis.

Bellini, S., Akulilan, J., Hopf, A. (2007). "Increasing Social Engagement in Young Children with Autism Spectrum Disorders Using Video Self-Modelling”. School of Psychology Review. 36(1): 80-90.

Bond, F. W \& Dryden, W. (2004). Handbook of Brief Cognitive Behavioural Therapy. England: John Willey \& Sons, Ltd.

Brown, H. D. (2004). Language Assessment: Principles and Classroom Practices. New York: Pearson Education, Inc.

Burns, A. and Goh, C. (2012). Teaching Speaking. New York: Cambridge University Press.

Cassady, J. C. (Ed.). (2010). Anxiety in Schools: The Causes, Consequences, and Solutions for Academic Anxieties. New York: PeterLang.

Celce-Murcia, M. (2001). Teaching English as Second or Foreign Language $3^{\text {rd }}$ Edition. Boston MA: Heinle \& Heinle.

Charlop-Christy M. H\&Daneshvar S. (2003). "Using video modelling to teach perspective taking to children with autism". J Posit Behav Interv 5(1): 12-21. doi: $\underline{10.1177 / 10983007030050010101}$ 
International Journal of Innovation, Creativity and Change. www.ijicc.net

Volume 13, Issue 6, 2020

Gai, F. \& Yang, D. (2010). “A study on college students' anxiety to spoken English". Canadian Social Science, 6(2). Retrievedfromhttp://www.cscanada.net, http://www.cscanada.org/

Gaibani, A and Elmenfi, F. (2014). "The Role of Gender in Influencing Public Speaking Anxiety". International Journal of Genderand Women's Studies, 2(2):105-116.

Galante, A. (2012). "The effects of drama on oral fluency and foreign language anxiety: An exploratory study". Doctoral dissertation. Canada: Brock University.

Gkonou, C. (2011). "Anxiety over EFL speaking and writing: A view from language classrooms". Studies in Second Language Learning and Teaching 1(2): 265-281, August. Retrieved from http://www.ssllt.amu.edu.pl/

Harmer, J. (2007). The Practice of English Language Teaching (Longman Handbooks for Language Teacher). New York: Longman Inc.

Horwitz, E. K. (2001). "Language Anxiety and Achievement".Annual Review of Applied Linguistics, 21:112-126.

Horwitz, E., Horwitz, E. M., \& Cope, J. (1986). “Language Anxiety Classroom”. The Modern Language Journal, 10:125-32.

Humphrie, R. (2011). "Language Anxiety in InternationalStudents:How can it beovercome?". Griffith Working Papersin Pragmatics and Intercultural Communication 4, 1(2): 65-77.

Javid, C. Z. (2014).'Measuring Language Anxiety in an EFL Context". Journal of Education and Practice, 5(25):180-192.

Jhonson, D. W., Jhonson, R.T. \& Smith, K. (2006). Active Learning: Cooperative in the College Classroom $3^{\text {rd }}$ Edition. Edina MN: Interaction Book Company.

Jones, L \& Petruzzi, D. C. (1995). "Test Anxiety: A Review of Theory and Current Treatment". Journal of College Students Psychotherapy 10 (1): 3-15.

Kim, S. Y. (2007). The Impact of Stereotypes on Public Speaking Performance and Anxiety. Published Dissertation. Georgia State University.

Kondo, S.S. \& Gifu, K. U. (1997). "Strategies Copying with Test Anxiety. Anxiety, Stress and Copying”. An International Journal 10 (2): 203-215.

Krannich, C. R. (2004). 101 Secrets of Highly Effective Speakers: Controlling Fear, Commanding Attention. New York: Listen and Live Audio Inc. 
International Journal of Innovation, Creativity and Change. www.ijicc.net Volume 13, Issue 6, 2020

Lin, et al. (2014). "Fun Learning Activities: The Antidotes of Anxiety in Public Speaking". International Journal of Asian Social Science, 4(2): 170-176.

Liu, H.\& Cheng, S. (2014). "Assessing Language Anxiety in EFL Students with Varying Degrees of Motivation". Electronic journal of Foreign language Teaching, 11(2) pp. 285-299 http://e-flt.nus.edu.sg/

Liu, M. \& Huang, W. (2011). "An Exploration of Foreign Language Anxiety and English Motivation”. Education Research International, 1-8. http://dx.doi.org/10.1155/2011/493167/

Louma, S. (2004). Assessing Speaking. Cambridge: Cambridge University Press.

Macleod, S. (2013). Behaviourist Approach. Online published.http://www.simplypsychology.org/behaviourism.html/ (Retrieved December $18^{\text {th } 2015) \text {. }}$

Mahmoodzadeh, M. (2012). "Investigating Foreign Language Speaking Anxiety within the EFL Learner's Interlanguage System: The Case of Iranian Learners".Journal of Language Teaching and Research, 3(3): 466-476.

Martin, D. and Miller. C. (2003). Speech and Language Difficulties in the Classroom $2^{\text {nd }}$ Edition.London: David Fulton Publishers.

Marzec-Sttawiarska, M. (2015). Investigating foreign language speaking anxiety among advanced learners of English. In M. Pawlak \& E. Klimczak (Eds.), Issues in teaching, learning, and testing speaking in a secondlanguage (pp.103-120). New York: Springer. http://dx.doi.org/10.1007/978-3-642-38339-7 7

Mayer, D. P. (2008). Overcoming School Anxiety. United State of America: AMACOM.

McCroskey, J. C. (2009). Making Friends with Your Public Speaking Anxiety Monster. Unpblished Report. New York.

McCroskey, J. C. (2013). "Personal Report of Public Speaking Anixety.Measurement Instrument Database for Social Science. Retrieved from www.midss.ie.com

Muijyanto, Januarius. (2016). "The dependence of verbal passages on visual representation in meaning-making". Prosiding Prasasti Journal, pp. 884-890.

Mokhlosa, W. \& Mukheef, A. A. (2020). A Pragmatic Study of Litotes in Trump's Political Speeches. International Journal of Innovation, Creativity and Change, 11(3), 112. 
International Journal of Innovation, Creativity and Change. www.ijicc.net

Volume 13, Issue 6, 2020

Nation, I. S. P. \& Newton, J. (2009). Teaching ESL/EFL Listening and Speaking. New York: Routledege, Taylor and Francis.

Nazir, et al. (2014). "A Study of Second Language Speaking-Anxiety among ESL Intermediate Pakistani Learners".International Journal of English Education, 3(3), 216-229.

Nikopoulos, C.S. (2007). "Use of Video Modelling to Increase Generalization of Social Play by Children with Autism". Journal of Speech-Language Pathology and Applied Behaviour Analysis, 2(2):195-212.

Nippold, M. A., et al. (2005). "Conversational versus expository discourse: A study of syntactic development in children, adolescents, and adults". Journal of Speech, Language, and Hearing Research, 48:1048-1064.

Noermanzah, Wardhana, D.E.C., Friantary, H., Arsyad, S. (2019). Joko Widodo's Rhetorical Structure in the Presidential Speeches for Addressing Educational Problems. International Journal of Scientific and Technology Research, 8 (10).

Onwoegbuzi, A.L and Dalay, C. E. (1996). "The Relative Contributions of ExaminationTaking Copying Strategies and Study Coping Strategies to Test Anxiety: Concurrent Analysis". Cognitive research and therapy 20 (3): 287-303.

Osborn, M. \& Osborn, S. (2014). Public Speaking: Finding Your Voice 10th ed. Boston: Houghton Mifflin.

Peng, J. (2014). Willingness to communicate in the Chinese EFL university classroom. Bristol: Multilingual Matters.

Piechurska-Kuciel, E. (2011). "The Relationship Between Language Anxiety and the Development of the Speaking Skill: Results of longitudinal study". In M. Pawlak and E. Waniek-klimczak (Eds.), Speaking and instructed foreignlanguage acquisition (pp.200214). Bristol: Multilingual Matters.

Pribyl, C., B, Sakamoto, M., and Keaten, J. (2001). "The Effectiveness of Skill-Based Program in reducing Public Speaking Anxiety”. Psychological Research, 43(3): 148-155.

Rector, N. A. (2010). Cognitive-Behavioural therapy: An Information Guide.Canda: Center Addiction and Mental Health.

Sanghvi, C. (1995). "Efficacy of Study Skills in Managing Study habits and Test Anxiety of High-Test Anxious Students”.Journal of Indian Academy of Applied Psychology 21(1): $71-75$. 
International Journal of Innovation, Creativity and Change. www.ijicc.net Volume 13, Issue 6, 2020

Scott, C. M., \& Windsor, J. (2000). “General language performance measures in spoken and written narrative and expository discourse of school-age children with language learning disabilities". Journal of Speech, Language, and Hearing Research, 43, 324-339.

Spiegler, M. D. \& Guevremont, D. C. (2010). Contemporary Behaviour Therapy. Belmont, CA. Wadsworth Cengage Learning.

Spielbelger, C. D. (1983). Manual for the State Trait Anxiey Inventory. California. Consulting Psychologists Press.

Sud, A and Prabha, I. (1996). Efficacy of Cognitive/Relaxation Therapy Outcome Studies. Unpublished Doctoral Dissertation. Texas Christian University.

Syafryadin, et al. (2019). Digitial Storytelling Implementation for Enhancing Students' Speaking Ability in Various Text Genres. International Journal of Recent Technology and Engineering, 8 (4), pp. 3147-3151.

Syafryadin, Wardhana, D.E.C., Apriani, E., Noermanzah. (2020). Maxim Variation, Conventional and Particularized Implicature on Students' Conversation. International Journal of Scientific and Technology Research, 8 (10). 3270-3274.

Tseng, S. (2012). "The Factors Cause Language Anxiety for ESL/EFL Learners in Learning Speaking". WHAMPOA - An Interdisciplinary Journal . 63:75-90.

Ur, P. (2012). A Course in language teaching practice and theory $2^{\text {nd }}$ Edition. United Kingdom. Cambridge University Press.

Young, D. J. (1992). "Language anxiety from the foreign language specialist's perspective: Interviews with Krashen, Omaggio Hadley, Terrell, and Rardin”. Foreign Language Annals, 25(2):157-172. http://dx.doi.org/10.1111/j.1944-9720.1992.tb00524.x/

Zerey, Ö. G. (2008). Impact of theater production on ELT students'foreign language speaking anxiety.Unpublished Master Thesis. Turkey : Mustafa Kemal University. 